\title{
Guru Bhakti and Panca Parmeșțīs, in the thought of Srimad Rajacandra (1867-1901 A.D)
}

Kamini V Gogri

Correspondence:

kaminigogri@gmail.com

Department of Philosophy, University

Of Mumbai, Mumbai, India

\section{Springer}

\begin{abstract}
Srimad Rajacandra who lived only for thirty-three years attained spiritual heights even while performing the duties of a householder. He gave importance to the inner spiritual development and stressed the need of spiritual teacher (sadguru) and the path of devotion (Bhakti) for such inner spiritual development. Srimad laid very much importance on Sadguru. According to him the teacher who is sanctimonious and enlightened and has self-experience is like God himself and devotion to him is devotion to God. Hence the individual who has found such a teacher should totally surrender to him and obey all his commands. The study of scriptures also should be done under the guidance of such a teacher; otherwise a person is likely to be misguided. An aspirant who aims at attaining liberation has to follow right knowledge, faith and conduct. Rajacandra says that spiritual knowledge consists in realizing with the help of the preaching of pious teacher, (a) that soul is different from body (b) that it has the inherent quality of knowledge and (c) that it is indestructible. Here what he tries to clarify is that in the process of acquiring right knowledge a teacher plays an important and significant role.

Pañca Parmeșthis, namely the Arihanta (Liberated but Embodied being), Siddha (Completely Liberated being), Ācārya (mendicant leader), Upädhyāya (an intellectually gifted renouncer), Sädhu (renouncer). Traditionally these categories alone designated the worship-worthy beings. They are the once to be venerated and worshipped. Srimad emphasized guru who necessarily may not be an ascetic but would be any lay follower who has attained the spiritual heights living a life of householder and emphasized that this person is a real ego less person who would help others in traversing the path of liberation. This contest with the traditional concept of Pañca Parmeșțis, wherein none other than them would be eligible for worship. His criteria of total submission to Sadguru, who is a living person, and through his grace one would definitely untie all knots and go ahead with his spiritual journey.
\end{abstract}

\section{Background}

Traditional Jainism venerates "Five Illustrious Beings" or Pañca Parmeșțisis, namely the Arihanta (Liberated but Embodied being), Siddha (Completely Liberated being), Ācārya (mendicant leader), Upādhyāya (an intellectually gifted renouncer), Sādhu (renouncer) Traditionally these categories alone designated the worship-worthy beings. One can also understand the Tirthankaras as those special virtuous souls who have attained ultimate eternal happiness by liberation for themselves and have also shown the path of liberation for others. Tìrthankaras literally means "builders of a ford" (or bridge), which leads across the sea of suffering (samsāra). The Tïrthankara is the personage who shows the path to

(c) 2014 Gogri; licensee Springer. This is an Open Access article distributed under the terms of the Creative Commons Attribution License (http://creativecommons.org/licenses/by/4.0), which permits unrestricted use, distribution, and reproduction in any medium, provided the original work is properly credited. 
liberation (moksa). Because this era is not favourable for the appearance of Tirthankaras ${ }^{\mathrm{a}}$, the aim of an aspirant should be to walk on path of salvation under the guidance of a sadguru.

The 19th century householder, Srimad Rajacandra, (hence forth referred as Rajacandra) propounded this view which challenged these ideas by introducing another worship-worthy category: the Sadguru - "true guru". He insisted that a guru, (who need not be an ascetic, but rather could be a spiritually advanced lay person), serves the crucial role of a guide in helping others traverse the path towards liberation. Such emphasis on an enlightened guru was novel in Jainism. So too were Rajacandra's ideas about the nature of guru-ship and the role the Sadguru play in religious life: Rajacandra maintained that the living guru possessed the power to "untie the knots" of bondage of his disciples, but only if they devote themselves to him fully. The path that Rajacandra introduced differed markedly from normative Jainism which emphasizes self-reliance and self-discipline as the only path to liberation. In Rajacandra's teachings, which express profound bhakti, Jains were called upon to set aside the path of self-effort in favour of total submission to the Sadguru. This paper will explore these ideas and ask why they were so readily received. That Rajacandra's teachings effectively turned the ideology of self-effort on its head, and -more importantly -- did so with little or no controversy. This raise some interesting questions about the relationship between "discursive Jainism", and its lived expression.

Interestingly, to those outside of the Jain community, Rajacandra is generally only known through his association with Mahatma Gandhi, who regarded Rajacandra as a brilliant philosopher, moral guide and friend.

\section{Rajacandra's analysis}

Much of Rajacandra's message is what we might call the stuff of traditional Jainism: for instance, he maintains that an aspirant who aims at attaining liberation has to follow what in Jainism are called the 3 Jewels: right faith, knowledge, and conduct (samyak darśana, jñāna, cāritra). He argues that spiritual knowledge consists in realizing the true nature of the soul, namely (a) that it is different from the body; (b) that it has the inherent quality of knowledge, and (c); that it is indestructible. Where Rajacandra deviates from traditional Jainism is in his insistence that such goals should be pursued under the guidance of a sadguru.

Where did such ideas develop from? We know that Rajacandra's family life was very pious: his grandfather was a devout worshipper of Krishna and his mother a Jain. In autobiography 'Samutchaya Vaya-charya, which he wrote at the age of twenty-two he says that he was "deeply dyed in the more colorful mode of worship of Krishna cult" Dinubhai et al. (1994). Interestingly, we know nothing about his father. It is likely that the intense devotional atmosphere in his home provided him with a "bhakti hermeneutic" through which to understand the teachings and scriptures of Jainism. Importantly, though devout and ascetic in his own practices, neither did he enter the mendicant life nor see this as essential to the Jain path; indeed as will be discussed below, he considered the householder life more conducive to spirituality. Moreover, he married, had five children, and worked as a jeweler. Despite this, he was able to devote considerable time to developing his own thought on religious matters, and attained great spiritual heights in his brief life (dying at the age of 33). What is intriguing is that although he placed an enormous emphasis on the need for a Sadguru, he himself was without one. 
Rajacandra described the sincere and truly enlightened guru as akin to God himself. Therefore devotion to him should be considered as devotion to God. According to Rajacandra, Bhakti is essential for inner spiritual development, and the individual who is fortunate to have found a true teacher should totally surrender to him. This means that he should completely follow all his guru's commands because they are in his own spiritual interest. The study of scriptures should also be done under the guidance of such a teacher; otherwise a person is likely to be misguided.

Samyak Darśana (correct faith) was, for Rajacandra, devotion to God/Guru, and should inform Samyak Jñāna and Samyak Cāritra. Indeed, this devotion to the true Guru superseded all else in importance. For Rajacandra, both self-effort and intellectual understanding are insufficient for self- realization. Worse, they are potentially harmful because both, mere external rituals and dry intellectualism, lead to the development of egoistic attitudes - the scourge of the spiritual path.

In his most influential text, Ātmasiddhi śāstra, Rajacandra was severely critical of intellectualism and ritualism, which he saw as dominating Jaina practice. The text lays out a devotional path that dispenses with both. This approach struck a chord among many within the Jain community, as it continues to do today. Many of its contemporary followers identify the absence of "empty ritual" as a central feature of the path.

"Besides a religious bigot mistakes the spiritual descriptions of the size etc of the body of the Jina and also those of the gorgeous decorations of the assembly halls where the Jina held congregations for the real descriptions of the Jina himself and his intelligence is so much engrossed in these externals that he neither knows the real nature of the Jina nor does he make sincere effort to comprehend it. A bigot, not knowing the metaphysical meaning of the scriptural descriptions of heaven and hell, take them as revealed knowledge. He also thinks that salvation can only come to him by his staunch adherence to his own religious opinion and adopted dress" Digish (1991).

Despite the challenges to the spiritual life in the kaliyuga, he assured his followers of the greatness of the bhakti path. In his letter No. 831, he states, "Even in this era, if the aspirant is unshakably firm in his determination and is mentally engrossed in the observance of the commands of a sadguru and practices valorously right knowledge, faith and conduct, he is entitled to the path of highest peace".

From V.S.1947 to 1951, for the first time he had the direct experience of atman as separate from body. This is called samakit or samyaktva. He then ardently desired to give up worldly life and become a nirgrantha muni. However his fight with external upadhi becomes quite active here. So this stage is marked with terrific battle or conflict between the two opposite forces. He feels like assuming the role of religious teacher for which renouncing worldly life and becoming a monk is a precondition (Pungaliya 1996).

\section{Sadguru, Satsañga, Bhakti}

In the order of Pañca Parmeșthī (the 5 Illustrious Beings of Jainism), Arihant and Siddha are the most extraordinary, because, of the 5 , they alone have attained liberation. The aim of the other worthies - the sādhus, upādhyāyas and ācāryas - is to attain the supreme state. They are honored because they are on the right path to realizing that goal. But even though they may have attained the highest of the scriptural knowledge, this - in and of itself - does not indicate their level of spiritual growth or enlightenment. Rajacandra was 
critical of institutionalized religion and sectarian divisions. Renouncers invariably belong to one of many Jain orders, organized as they are into four-fold sanghas (male and female renouncers, male and female householders) - a traditional structure of Jainism at least since the time of Mahavira. While such structures are beneficial for social cohesion, they can be hindrances, according to Rajacandra, for the spiritual path. Although renouncers guide people through their discourses, the structural imperatives of the ascetic order can impede true spiritual exchange. Renouncers ordained in a particular institution must follow sect-specifically prescribed rules that have more to do with sectarian differentiation than with self-realization. Furthermore, Rajacandra argued that they often meticulously follow the external rituals mentioned in the agamas (e.g., pratikramana) with more attention to their punctilious performance than the spiritual intentionality underpinning them. As a consequence, time that could be devoted to sādhanā is wasted in the mere performance of empty rituals. Importantly, Rajacandra was critical of asceticism because he felt the institution served to create an artificial bubble, divorced from everyday life. Renouncers, he argued, cannot guide people properly about their spiritual development due to their inability to grasp the spiritual life of the common people. Interestingly, he was even critical of the path of celibacy, incumbent upon renouncers. He once argued, perhaps ironically, that since human birth is so difficult to obtain, and mokșa only available from this human state, it should be our duty to see that children are born. "Religion advocated by Mahavira was not a creation of his own. The only thing he did was the organization of moral and disciplinary aspects of the then existing Jaina church. That he stood for a stricter code of discipline of the body and of the mind is evident from his inclusion of the fifth vow of celibacy to the aggregate of four vows of Parsva" Deo (1952). Rajacandra stresses the need of a sadguru (alternatively called a satpurușa); an individual free of institutional barriers who can communicate, forthrightly with another soul, and to whom an individual can completely devote. The sadguru is a real self-enlightened person who is far away from external rituals, passions, and institutional obligations; he is completely engrossed in the soul. It is worth noting that Rajcandra's ideas about female spirituality are unknown. His total neglect of the role of sadhvis is surprising, given that female renouncers have always played an important role in the Svetambara Jain community from which he came.

In part 3 of Rajacandra's text's Upadeśa Chāyā, he maintains that respectful surrender and submission to a pious teacher is itself "samyaktva" (knowledge of the soul). This is a momentous claim, given that the entire Jain path of self-discipline and renunciation can be understood to be seeking after samyaktva. The sadguru is a person who teaches and makes us understand true divinity (Sat - Devatā) and real teacher (Sad-Guru), because he himself has traversed the path and therefore is aware of the path and the hurdles in self- realization. He divides Samyaktva (or Samkita) into two types. The first is practical (Vyavahära) samkita, denoting the path by which an aspirant listens to the sadguru's preaching, broods over them, and tries to dutifully put the truths into practice. In this way, he eventually comes to experience them as true. The second type is that of spiritual samkita or samyaktva, the acquisition of which denotes a sudden, total internal transformation in an aspirant.

In Rajacandra’s Mokșa Māā he introduces the importance of the satsangga, which we can translate as the "community in truth" or "auspicious company". Rajacandra elaborates on the importance of such a community for spiritual growth. Given Rajacandra's 
focus on relationship (with the sadguru, for instance, instead of the path of solitude) it follows that he considers proper inter-personal relations to be central for the religious adherent. A pious community is a great source of help for the seeker to be free from passions and egotistical desires, and to assist him or her along the path of self-realization.

In a language more familiar to traditional Jainism, Rajacandra in Mokșa Mālā also stresses the importance of meditation. Indeed, at one point he states that meditation is "the best means of sādhanā for spiritual progress and realization" But for Rajacandra, while meditation is an important tool for those whose aim is self-realization, it should not be undertaken independently of the guru. In one of Rajacandra's correspondences, he warns an aspirant that to meditate or preach without the guidance of a sadguru is nothing but a wave: it may bring a sudden and powerful experience of the soul, but it will disappear as fast as it arrives. He says that spiritual transformation (samyaktva) can take place only in satsan்ga of a pious teacher, because the guru alone can make us understand the true meaning of religion.

He maintains that engagement with the guru should precede meditation: an aspirant should begin by having a dialogue with the sadguru. Only after the disciples doubts are removed, should he undertake deep reflection. He should then go to a place where there is no disturbance, contemplate on the real nature of the self and thereby come to know the true spirit in one's own self. When one's knowledge is fully purified, one can be said to have attained Kevala Jñanna (Omniscience). This knowledge, according to Rajacandra, is not the knowledge of the external world (of substances) but rather the purified knowledge of the self.

This for Rajacandra, is tantamount to "religion". Religion, in other words, is nothing other than self-realization - a passionless state, devoid of raga and dveșa, (aversion and craving). As we saw above, he was critical of sectarian divisions and empty ritual, insisting instead that true religion was concerned only with the realization of the intrinsic nature of the soul. Religion is to be aware of the soul's internal characteristics of unlimited knowledge, faith, power and bliss.

In a statement that encapsulates both traditional Jain teaching and his reforms, Rajacandra asserted that, "One cannot be free from misery unless one is free from passions and ignorance; and one cannot be free from passions and ignorance unless one acquires Ātma Jñāna. Therefore, one must surrender to and obey a pious teacher. This is so because such a teacher, and not the so-called preacher, is one who knows and realizes what the soul is, and is always engrossed in its true nature". Interestingly, even though the enlightened sadguru would never desire nor seek after devotees, he needs them in order for his wisdom to be effective, and the aspirant, who desires to be liberated, must become a devotee. Rajacandra writes that without disciples the sadguru's preaching cannot yield any fruit. The Sadguru responds out of compassion, not out of desire. He is a great support, a solace and a refuge. Indeed, the role of the sadguru is a totalalizing presence in the life of the disciple: whatever peace an aspirant experiences in life should be understood as due to auspicious karma, which in turn is due to the favor of the sadguru who alone is effective in bringing about supreme happiness.

\section{Discussion}

The ideas that Rajacandra introduced were truly innovative in the Jaina tradition. While not uncommon in other traditions, the concept of total submission to a guru was absent and, 
indeed, long rejected. Even the Tïrthankkaras are not said to change the fate of another person, at least according to the traditional understandings of Jainism. Every soul has to work out on its own salvation, through the 12 forms of nirjarā (efflux of karma). Secondly, submission evokes the arousal of feelings, emotions and sentiments towards a higher authority, and such sentiments have always been problematized in the śramanic path. In the Jaina tradition, feelings are regarded as leading to the binding of Mohaniya Karma, the most inauspicious form of karma which must be destroyed in order for Vitarāgatā to be attained (that is, a state in which one has overcome passions completely). But followers of Rajacandra dismiss the existence of a conflict with traditional Jain teachings as mistaken, and argue that resemblances between ordinary ego-feelings and feelings for surrender to a sadguru are outward appearances only. Ordinary ego-driven desires or feelings are motivated by passions and are directed towards worldly goals. While the desire to surrender is the result of no ego-desires or passions, and neither is it directed to any worldly goal. It is argued that it would be mistaken to include the desire for spiritual surrender in the class of Mohanīya karma. (The same controversy is found between kāma purușārtha and mokșa purușārtha in Hindu tradition).

Nevertheless, Jainism is suspicious also of claims to "surrender" to another human being because of the latter claims to possess a higher authority, as Rajacandra's teachings seem to do. If all souls are equal, then how can there be submission to another soul? Even the worship of Tîrthankkaras does not involve the submission to them, but rather, Jainism holds that by venerating them the aspirants come to inculcate in themselves practices that will help them to attain the true self. Submission presupposes a relationship between two individuals or between an individual and "God". In Rajacandra's writings, submission on the part of the disciple and grace on the part of the guru is fundamental to the spiritual path. This concept of grace was never envisaged in Jainism. The Jina is the centre of Jain devotional life, but he is not considered to respond to his devotees. In a state of mokșa, he is outside of all worldly concerns. In his book, Absent Lord, Lawrence Babb puts it this way: "From the standpoint of transactional logic, the Tïrthankkara is absent. He responds to no prayers or petitions, and dispenses no saving grace" (1996: 92). Traditional Jainism insists that our spiritual progress comes through our own efforts alone. Rajacandra's teachings seem to turn traditional shramanism on its head with its claims that only through the guru's grace, love and affection can the aspirant move ahead.

Rajacandra's ideas were innovative, but they were not without precedent. Though Jainism and Buddhism are India's major Śramanic traditions, we find that, in both, the profounder of the non-theistic religions themselves came to be worshipped as gods. Indeed archeological evidence points to the existence of Jain images as early as the 6th century B C E, suggesting some form of cultic practice of worship from a very early period $^{\mathrm{b}}$.

The Jainas thus began slowly to move away from Magadha, becoming established in various cities along the two great caravan routes; one of these led North West, towards Delhi and Mathura thence South and West through Saurashtra and into Gujarat, while the others followed the East coast South- ward into Kalinga (modern Orissa), finally reaching even to the Dravidian lands around Madras and Mysore" Jaini (1990).

Between c. 200 B.C. and c. 300 A.D. important changes took place within Jainism, where we observe the emergence of idol worship and expansion of the Jaina pantheon 
far beyond the Jinas, incorporating new and local deities. In the course of time, the worship of the idols of the Tïrthankkaras was incorporated as an important religious activity. Increasingly, the emphasis came to be placed on external worship, and the person who performed such worship came to be regarded as especially pious. With the growth of temple building all over India, the practice of visiting them as places of pilgrimages grew in importance, especially those places where Tīrthan்karas have attained the auspicious events of their life. The late medieval period witnessed a great flourishing of bhakti traditions and saints, such as Dādū, Sūra, Tulasī, Mīrā, and Guru Nānaka. By the late medieval period, according to Dr J.C. Jaina (in his book, Studies in Early Jainism), Jain dharma "was not confined to jñāna (knowledge) but it reaffirmed Bhakti, emotional feeling, devotion, adoration, glorification and paying homage to God"c. Bhakti had become formally integrated into mainstream Jain practice. For instance, the caturvirnsśati-stavana (eulogy to 24 Tïrthanikaras) and vandanā (salutation to God Jina-Arhant and Siddha) came to be considered as among the six obligatory duties (șa âavaśyaka) of a Jain. In addition, then ten types of Bhakti come to be seen as integral to Jainism. They are: Bhakti to Tirthankara, to Siddha, to Śruta (scripture), to cāritra (conduct), to monk, to ācārya, to nirvāṇa, to Pañcaguru (five teachers), to nandíśvara continent, and to śānti (peace). Kundakunda refers to Pūjā of devatā (jina), yati (monk) and guru (teacher) ${ }^{\mathrm{d}}$.

So we can see that although basic to the śramana tradition is the idea that emotions are to be arrested because they are a major cause of bondage, a positive exploration of inner sentiments through devotional practices have existed throughout Jainism's long history ${ }^{\mathrm{e}}$. Perhaps we see it culminating in the writings of the celebrated lay man Rajacandra and in the movement his writings have spawned. Though the teachings of Rajacandra came out of an already devotionally fertile soil, the novelty of his message nevertheless marks a significant shift in orientation. The bhakti that had become traditional in Jainism was primarily centered on divine service (mainly in the form of rituals directed toward the Jinas). The type of bhakti that Rajacandra introduces, in its insistence on surrender to a guru, is of a different nature. The fact that Rajacandra is celebrated by a great number of Jains, in numbers that far exceed his own specific devotees, suggests that his ideas are, if not mainstream, hardly controversial.

Following Rajacandra's death, one of his most ardent followers, a monk by the name of Laghuraja Swami established a Rajacandra Ashram at Agas. Today, Rajacandra's teachings have spawned several large and prosperous followings, both in India and abroad. His followers believe that his writings literally embody the message of the Jinas, and that he was a truly enlightened being who, even in death, continues to guide humanity through enlightened teachers. Arguably, the most important such teacher today is Rakesh bhai Jhaveri (Pūjya Gurudev) a living disciple of Shrimadji who is believed to incarnate his Guru's teachings and blessings, and who oversees an extensive ashram in Dharampur, Valsad. But there are others, notably in Koba (near Ahmedabad), Deolali (near Nasik). These ashramas are complexes consisting of temples, meditation halls, libraries, guesthouses, short-term residences, and hospital.

\section{Conclusion}

To conclude Rajacandra's assurance that path of Guru Bhakti will lead the aspirants on the ladder of spiritual growth, a state of spiritual freedom. Rajacandra's teachings express 
profound devotion. Jains are here called upon to set aside the path of self -effort in favor of total submission to the sadguru. From the perspective of discursive Jainism, this is definitely unorthodox and even controversial. But whether or not it is within the lived tradition, is an open question.

\section{Endnotes}

${ }^{a}$ Tirthankaras only appear during certain times in the vast time cycles. Jains believe in eternal cycles of time with rise and decline. Utsarpini is a "rising" era in which human morale and natural conditions improve over time. At the end of Utsarpini, begins Avasarpini, a "declining" era of the same length, in which human morale and virtues deteriorate. During the middle of every rising and declining era there are infinite souls who attain liberation but out of them only twenty-four souls become Tirthankaras. While accumulating different karmas in past lives, they also accumulate and get a special karma called Tirthankar Nam Karma in the last 3rd of their life by performing one or more of the 20 special austerities. Tirthankar Nam Karma matures in the final life and leads the person to become a Tirthankara.

${ }^{\mathrm{b}}$ K.L Chanchreek and Mahesh Jain, Jaina Economic Life, p. 137.

'J. C. Jaina , Studies In Early Jainism, p. 173.

${ }^{\mathrm{d}}$ Paraphrased from J.C Jaina, p. 173.

${ }^{\mathrm{e}}$ This is not to suggest there was unanimous, universal acceptance of bhakti within Jainism. For example. Vattkera (circa $2^{\text {nd }}$ century A.D.) a Jaina ācārya from south India was an early critic. He argued that a saint who, prays to the Jina for freedom from birth and death, for enlightenment (bodhi-lābha) and for the preservation of auspicious thoughts at the time of Samādhi Maraṛa (death while in meditation) engages in false speech (asatya- mrșā). If he achieves greatness it is in spite of, not because of, such devotional outpourings. The same idea is conveyed by Samantabhadra, another renowned Digambara Jaina author of the $5^{\text {th }}$ century in his Āptamimārṇsā. Despite such voices of dissent, the lifeblood of Jainism continued to be devotional, or perhaps more modestly, continued to combine śramaṇic and devotional elements.

Competing interests

The author declares that she has no competing interests.

Received: 19 June 2014 Accepted: 22 October 2014

Published online: 11 February 2015

\section{References}

Deo, SB. 1952. History of Jaina Monachism. Pune: Deccan College. p 278.

Dickens and Tokin. 1985. The Reformation in Historical Thought. U.K: Basil Blackwell Ltd.

Digish, Mehta. 1991. Shrimad Rajachandra: A Life. Agas: Shrimad Rajachandra Ashram. p,13-14.

Dinubhai, Patel, and Govardhandasji (tr.). 1994. Self - Realization of Rajacandra Rajachandra. Agas: Shrimad Rajachandra, Ashram.

Dixit, KK. 1978. Early Jainism. Ahmedabad: L.D. Institute of Indology.

Jaini, PS. 1990. The Jaina Path of Purification. Delhi: Motilal Banarsidasa. p 278.

Pungaliya, UK. 1996. Philosophy and Spirituality of Rajacandra Rajachandra. Jaipur: Prakrit Bharati Academy. p 27 